\title{
The Moderating Role of Leader-Member Exchange on the Relationship between Emotional Labor with Job Satisfaction or Turnover Intention
}

\author{
Hakan Turgut ${ }^{1}$, Ismail Tokmak ${ }^{2} \&$ M. Fikret Ates ${ }^{1}$ \\ ${ }^{1}$ Başkent University, Ankara, Turkey \\ ${ }^{2}$ Minister of National Defense, Ankara, Turkey \\ Correspondence: M. Fikret ATES, Vocational School of Social Sciences, Başkent University, Ankara, Turkey. Tel: \\ 90-532-726-2680. E-mail: mfates@baskent.edu.tr
}

Received: July 18, 2016

doi:10.5539/ijbm.v11n12p83

\footnotetext{
(1)
}

Accepted: October 26, 2016

Online Published: November 20, 2016

URL: http://dx.doi.org/10.5539/ijbm.v11n12p83

\begin{abstract}
It is known in the business world that employees' display of emotional labor in their relations with customers contributes to the success of the organization. Therefore, the aim of this study is to find out how the emotional dilemmas that employees experience affect their perceptions on job satisfaction and turnover intention and whether leader-member exchange has a moderating role on these relationships. In this respect, we performed a survey on the 371 employees of a company in Turkey. We used the scale developed by Diefendorff et al. (2005) to test emotional labor; the scale developed by Scandura and Graen (1984) to test leader-member exchange; the scale developed by Chen et al. (2009) to test job satisfaction and the scale developed by Scott et al. (1999) to test turnover intention. The all scales were measured valid and reliable for this sample group. In the hierarchical regression analyses, done to test the hypotheses, all variables were included in the model. According to the findings, emotional labor has a significant and positive direct effect on turnover intention and it has a significant and negative direct effect on job satisfaction. All these results taken into consideration, it was confirmed that when emotional labor increases, turnover intention also increases, and job satisfaction decreases. Furthermore, the moderating role of leader-member exchange between the relationship of emotional labor and turnover intention wasn't approved; however, its moderating role between the relationship of emotional labor and job satisfaction was approved. To sum up, it is estimated that performing emotional labor is inevitable for organizational success and it is essential to develop new methods in order to prevent the negativities resulting from emotional dilemmas.
\end{abstract}

Keywords: emotional labor, job satisfaction, leader-member exchange, turnover intention

\section{Introduction}

The meaning of the concept of being customer-focused in the organizations where modern management adopts the approach "the customer is always right", has turned into the effort of meeting the expectations and the needs of current clients unconditionally and maintaining those (Akgeyik \& Güngör, 2013). In order to make sure that customers buy the same product or service again, service providing employees' attitudes and behaviors are expected to be compatible with the targets (Özdemir, Yalçın, \& Akbıyık, 2013). Within this framework, the dependent and independent variables assumed to affect the efforts of becoming customer focused are presented below:

Emotional labor was defined as the display of emotions (Goodwin, Groth, \& Frenkel, 2011) of the employees who have face to face and instant interactions with customers and in addition to their physical and cognitive contributions (Diefendorff, Morehart, \& Gabriel, 2010), organizing (Kart, 2011) these emotions supporting the essential behavior in the organization (Akgeyik \& Güngör, 2013) which transformed into culture, regardless these emotions are different from their own or not (Güngör, 2009). The theoretical origin of Hochschild's (1983) emotional labor based on the principles of Blau's (1964) social exchange theory and Gouldner's (1960) reciprocity theory.

In order to explain emotional labor, Hochschild (1983) developed factors of "deeply act" meaning "the effort of experiencing the emotions the job requires" and "surface act" meaning "displaying the emotions the job requires 
instead of the ones they really feel". Later on Ashforth and Humprey (1993) added a third factor called "natural feelings" meaning "the individual's real emotions corresponding with the ones the job requires" (Brotheridge \& Grandey, 2002; Grandey, 2003; Tokmak, 2014).

Job satisfaction (JS) is the indispensable precursor of organizational success, one of the most important business manners that emotional labor can affect (Ghalandari \& Jogh, 2012; Jiang, Jiang \& Park, 2013). The leadership of job satisfaction is formed by the contribution of positive manners and behaviors developed as a result of the employees' evaluation of their jobs and achievements (Locke, 1976; Chen et al., 2009; Başbuğ, 2010). In this respect job satisfaction has different perspectives such as employees develop manners resulting from their beliefs, emotions and evaluations towards their jobs and they believe that they get as much as they give (Jiang \& Park, 2013). In addition to these, job satisfaction may also be defined as a critical psychological fact associated with achievements such as motivation and efficiency (Jyoti, 2013).

In the theoretical origin of job satisfaction, when Herzberg's (1959) motivational and hygiene factors (salary, reward, promotion opportunity, physical conditions, etc.) are ensured or similarly, according to Adams's (1963) equality theory, if employees realize the "input-output balance" between their efforts and earnings, they experience job satisfaction and if they cannot realize it, they experience job dissatisfaction (Goodwin et al., 2011). Besides, it has been presented that job dissatisfaction is an important element that leads employees to turnover intention (Chau, Dahling, Levy, \& Diefendorff, 2009; Bouckenooghe, Raja, \& Butt, 2013).

Turnover intention includes the thought of leaving the job soon or the possibility of getting a new one (Mobley, 1982; Hom, Caranikas, Prussia, \& Griffeth, 1992; Bouckenooghe et al., 2013). Turnover intention is a process which is affected by many elements and when it is followed by their signations of the highly successful employees, it affects the organizations negatively by causing labor loss and disturbing the workflow (Hom et al., 1992; Beğenirbaş \& Çalışkan, 2014). Job satisfaction is experienced when the manners of the employees towards their jobs and organizations, knowledge, experience and emotions are positive, whereas job dissatisfaction is experienced when they are negative and in further factors turnover intention is experienced (Chau et al., 2009; Goodwin et al., 2011).

Vroom's (1964) expectancy theory is effective in explaining the ideas and their reasons that turnover intention is based on. Performance increases when job satisfaction is high and therefore reactions such as disappointment and turnover intention are less encountered (Goodwin et al., 2011). Among the elements that affect employees' turnover intention, their relationship between their managers or leaders is regarded as a very important one (Bauer \& Green, 1996; Gerstner \& Day, 1997). In this respect, it is assumed that turnover intention which occupies an important place among organizational results that leader-member exchange quality can affect will probably decrease.

Leader-member exchange has brought a different point of view to leadership emphasizing "vertical dyad linkage" which is found between the members and the leaders and is ignored by other organizations (Dansereau, Graen, \& Haga, 1975; Graen \& Uhl-Bien, 1995). Leader-member exchange suggests that leaders will have a better interaction with the employees they work closer with and they will have an ineffective interaction with the employees they don't know well and this interaction creates a differentiation both on their behaviors and on the results (Gerstner \& Day, 1997; Burns \& Otte, 1999). This differentiation is assumed to affect other business manners as well (Avcı \& Turunç, 2012).

Blau's (1964) social exchange theory, Kahn and his friends' (1964) role theory, and Vroom's (1964) expectancy theory are theories that leader-member exchange is based on (Graen \& Scandura, 1987; Graen \& Uhl-Bien, 1995). Within this scope, it is suggested that the nature of the roles that are displayed by the members is shaped by the quality of the interaction developed with the leaders (Lunenburg, 2010). By the help of high quality leader-member exchange, the members obtaining mutual respect, trust, more support and resources are assumed to be getting more responsibility and showing a higher performance in order to respond their leaders positively (Nishii \& Mayer, 2009).

The aim of this study is to study the emotional labor behaviors of the cargo workers and to determine whether leader-member exchange they have with their leaders has a moderating effect on the relationship between emotional labor and job satisfaction and emotional labor and turnover intention. The relationships between variables found in the related literature are presented Part Two. It is evaluated that the results of this study will contribute not only to the literature but also to business managers who seek to get more performance from labor force. 


\section{Literature Review and Hypotheses}

\subsection{The Relationships between Emotional Labor and Variables}

There are significant studies on employees pretending to feel the emotions that they don't actually feel (Yildirım \& Erul, 2013) and displaying emotional labor, which affects their business manners and behaviors negatively (Hochschild, 1983; Biçkes, Yılmaz, Demirtaş, \& Uğur, 2014). Glomb and Tews's (2004) emotional dissonance theory is used (Cote \& Morgan, 2002; Judge, Woolf, \& Hurst, 2009) to conceptualize the idea that emotional dilemmas trigger negative business results caused by the differences between emotions which are expected from the employees by the organization and the ones they experience inside themselves.

While emotional dissonance theory emphasizes that forced emotional labor of the employees causes negative results, job dissatisfaction emphasizes that displeasure, exhaustion and an increase in turnover intention cause decrease in work performance (Grandey, 2003). Studies on this subject emphasize that emotional labor the organization asks for or forced emotional labor displayed by certain emotions the job requires cause employees to show more job dissatisfaction or turnover intention after some time (Cote \& Morgan, 2002; Öz, 2007; Chau et al., 2009; Güzel, Gök, \& Büyüker, 2013; Beğenirbaş \& Çalışkan, 2014).

In the studies focused on the relationship between job satisfaction and emotional labor, as surface act and deeply act, the sub factors of emotional labor create emotional dilemmas, employees experience job dissatisfaction (Morris \& Feldman, 1997; Grandey, 2003; Oral \& Köse, 2011; Başbuğ, Ballı, \& Oktuğ, 2010). Moreover, there are significant findings that emotional labor displaying employees' JSs are affected positively (Wharton, 2009). The fact that employees' experiencing positive emotions has a negative relationship with surface act, whereas it has a positive relationship with deeply act has been proved (Gosserand \& Dienfendorff, 2005). There are also studies which show that NF, the factor of emotional labor, affects job satisfaction positively (Ghalandari \& Jogh, 2012; Yin, 2012).

\subsection{Moderating Role of Leader-Member Exchange}

The businesses which have adopted the motto "the customer is always right" have experienced some unpleasant events leaving both the leaders and the members in a difficult position emotionally. When they encounter such events causing emotional stress, leaders should motivate their members and the members should "service with a smile", so both parties are expected to display emotional labor (Grandey et al., 2005; Gardner, Fischer, \& Hunt, 2009; Humphrey, 2012). In this respect, it is proposed that, employees who have a good leader-member exchange need to feel that they're supported by their leaders to be able to display their emotions concerning the expected positive business manners (Gerstner \& Day, 1997; Nishii \& Mayer, 2009; Oral \& Köse, 2011; Buch, 2015).

Studies on leader-member exchange show that by the help of outcomes such as high performance, career opportunities and low level of stress, job satisfaction between the leader and the members' increases (Bauer \& Green, 1996; Brotheridge \& Grandey, 2002; Hackett \& Lapierre, 2004; Janssen \& Yperen, 2004; Epidropaki ve Martin, 2005; Bang, 2011; Çekmecelioğlu \& Ülker, 2014). However with poor leader-member exchange members aren't able to interact with the leader much and have fewer resources, and this leads to job dissatisfaction, decreasing the commitment towards the organization and increasing the turnover intention (Vecchio \& Gobdel, 1984; Gerstner \& Day, 1997; Nishii \& Mayer, 2009; Şahin, 2011).

In this context, some researchers have anticipated and detected a negative relationship between leader-member exchange quality and turnover intention (Vecchio \& Gobdel, 1984; Gerstner \& Day, 1997). In some studies it has been pointed out that the relationship between leader-member exchange and turnover intention is a curvilinear relationship rather than a linear one (Harris, Kacmar, \& Witt, 2005; Morrow, Suzuki, Crum, Ruben, \& Pautsch, 2005). According to this, if the quality of leader-member exchange is low, the turnover intention of the employees increases and otherwise it doesn't always decrease. In other words, sometimes even when the quality of leader-member exchange is high, an employee might consider leaving the job. Because of this, despite the results obtained from the literature, high quality leader-member exchange is expected to have a moderating role on the negative relationships of emotional labor with job satisfaction and turnover intention.

\section{Methods}

\subsection{Research Model}

In literature analysis despite the efforts of explaining emotional labor with surface act, deeply act and natural feelings factors in a positivist approach, it is obvious that there is no agreement on whether it has a positive or a negative effect on job satisfaction or turnover intention. This uncertainty results from emotional labor consisting factors that have very similar features and that a certain differentiation cannot be made. Furthermore, employees, 
showing extra effort for the compulsory emotions and manners that are expected from them although they don't exist in their job description, no matter which factor of emotional labor they're in, are sure to be worn out. Therefore in this study holistic paradigm, which was defined as "a system is considered a whole with its parts, parts themselves cannot represent the whole separately" by Jan C. Smuts (1926) was preferred. When holistic paradigm takes emotional labor as a whole and it considers it as single factor, its effect on manners is considered as inevitable. So emotional labor displaying cargo workers' job satisfaction is expected get lower whereas their turnover intention is expected to get higher.

As the result of literature study, the relationships between emotional labor, which was considered as single factor by Holistic Paradigm and JS-TOI were analyzed and hypotheses and the research model questioning whether leader-member exchange has a moderating effect in these relationships were presented in Figure 1. The study was done by analyzing the collected data with an e-survey. Confirmatory factor analyses were done by using the program AMOS 6.0 and others were done by using SPSS 19. Below is a sample of the study and the scales used in this study:

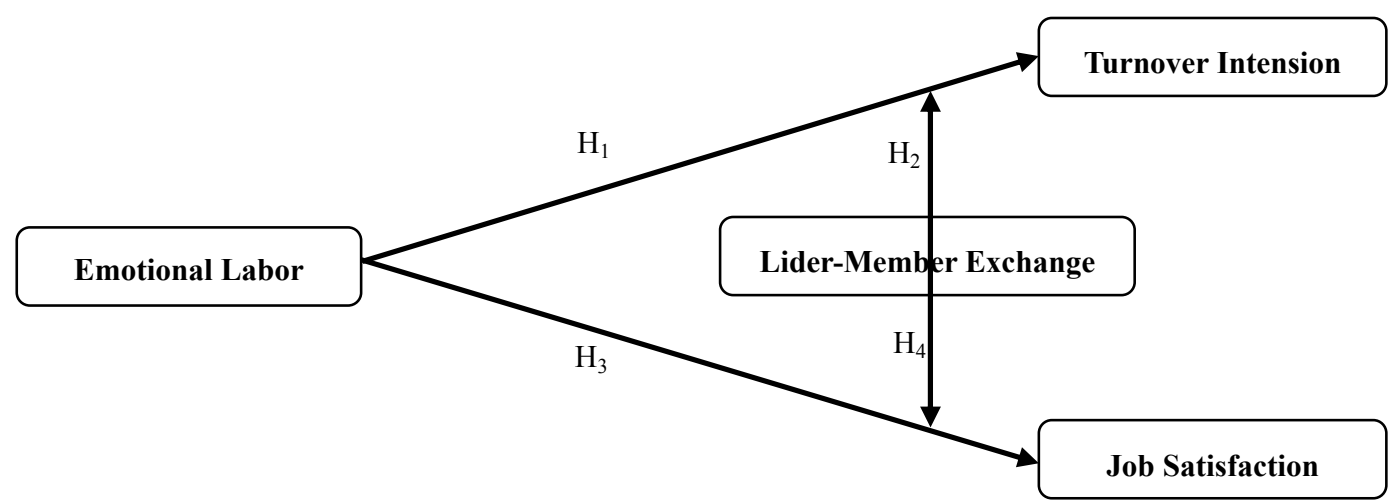

Figure 1. Research model

$\mathbf{H}_{\mathbf{1}}$ : There is a significant and positive relationship between emotional labor and turnover intention.

$\mathbf{H}_{2}$ : There is a moderating role of leader-member exchange on the relationship between emotional labor with turnover intention.

$\mathbf{H}_{3}$ : There is a significant and negative relationship between emotional labor and job satisfaction.

$\mathbf{H}_{4}$ : There is a moderating role of leader-member exchange on the relationship between emotional labor with job satisfaction.

\subsection{Sample}

The nature of the study consists of the employees of an Istanbul-Turkey based cargo company which operates in logistics sector and has a total of nearly 10.000 employees in its main branch and other branches and they are all eager to have a one-to-one interaction for customer satisfaction. After getting permission from the management, the survey was sent online via company intranet to the accounts of the employees on 11 January 2016 and it was announced that data collecting process would be completed on 31 March 2016. A total of 371 people completed the survey between the dates 11 January-31 March 2016.

As the prepared e-survey didn't let the participants give more than one answer o each question or skip a question, all the data was included in the study. It is suggested that for a parameter of 10.000 the sample size $(\alpha=0.05$, sampling error $\mathrm{H}= \pm 0.05$ and rates $\mathrm{p}=0.5 ; \mathrm{q}=0.5$ ) has to be at least 370 (Ural \& Kılıç, 2011). Detailed information about the participants is given in Table 1 . 
Table 1. Demographic features

\begin{tabular}{|c|c|c|c|c|c|}
\hline Sex & $\mathbf{n}$ & $\%$ & Age & $\mathbf{n}$ & $\%$ \\
\hline Female & 45 & 12.1 & $20-30$ & 93 & 25.1 \\
\hline Male & 326 & 87.9 & $31-40$ & 182 & 49.1 \\
\hline Marital Status & & & $41-50$ & 88 & 23.7 \\
\hline Married & 251 & 67.7 & $51-60$ & 8 & 2.2 \\
\hline Single/Divorced & 120 & 32.3 & Occupational Experience & & \\
\hline Education & & & Less than 1 year & 8 & 2.2 \\
\hline Primary & 83 & 22.4 & $1-5$ years & 98 & 26.4 \\
\hline Secondary & 92 & 24.8 & $6-10$ years & 88 & 23.7 \\
\hline High & 129 & 34.8 & $11-15$ years & 101 & 27.2 \\
\hline Associate & 17 & 4.6 & More than 15 years & 76 & 20.5 \\
\hline License & 48 & 12.9 & Tenure & & \\
\hline Master & 2 & 0.5 & Less than 1 year & 38 & 10.2 \\
\hline Position & & & $1-5$ years & 129 & 34.8 \\
\hline Manager & 63 & 17.0 & $6-10$ years & 108 & 29.2 \\
\hline \multirow[t]{2}{*}{ Employee } & 308 & 83.0 & $11-15$ years & 68 & 18.3 \\
\hline & & & More than 15 years & 28 & 7.5 \\
\hline
\end{tabular}

According to this, it is thought that the size of the sample, consisting 371 employees who responded via online, is enough. $87.9 \%$ of the participants are male, $67.7 \%$ are married, $17 \%$ are managers, $52.8 \%$ of them have high school or higher education, $74.2 \%$ of them are under the age of 40 or below, $53.6 \%$ have an occupational experience of 1-10 years in their work life, $51.2 \%$ have 5 years or less tenure in the current company.

\subsection{Measures}

The survey form used in this study consists of six parts. In the first part the aim of the study is explained and information about how to do the survey is given. In the second part there are questions to determine the participants' demographic features (Table 1). There are expressions about emotional labor in the third, leader-member exchange in the fourth, turnover intention in the fifth and job satisfaction in the sixth and the final part. By this e-survey form, the participants are prevented from giving more than one answer to a question or leaving it empty.

\subsubsection{Emotional Labor Scale}

To measure the participants' emotional labor perceptions, the scale which was developed by Diefendorff et al., (2005) and adapted into Turkish by Basım and Beğenirbaş (2012) was used. The scale consists of three different factors and a total of 13 items. The first factoris surface act (6 items), the second factor is deeply act (4 items) and the third one is natural feelings ( 3 items). The participants determine how much they agree with expressions such as; "I pretend to be able to deal with the customers in a proper way", "I display different emotions to customers than the ones I really feel inside", "the emotions I display come out naturally" with a 5 Likert Type scale.

\subsubsection{Leader-Member Exchange Scale}

Scandura and Graen's (1984) LMX7 scale was used to measure the capital levels of the participants' leader-member exchange levels. The Turkish adaptation of this scale was used in the studies of Özutku, Ağca, and Cevrioğlu (2008), Karcıoğlu and Kahya (2011), and Bolat (2011). The scale prepared for the leader and the members consists of 7 statements for each. In this study, the participants who declared that they are leaders, responded to questions such as "My business relationship with the members is effective", and "I trust my leaders so much that I will defend their decisions even when they are absent". The participants who declared that they are not leaders responded to questions such as "My business relationship with the leaders is effective" and "My leader trusts me so much that he will defend my decisions when I am absent", The participants determined how much they agree on the statements by the help of a 5 Likert Type scale.

\subsubsection{Turnover Intention Scale}

For the measurement of the participants' turnover intention, the scale which was developed by Scott and his friends (1999) and adapted into Turkish by Aylan (2012) was used. The scale consists of a total of 4 statements one of which is negative; such as 'I am planning work here until I retire' and "I am seriously considering of 
looking for another job in the coming year". A 5 Likert Type scale was used.

\subsubsection{Job Satisfaction Scale}

The job satisfaction perceptions of the participants were measured by the job satisfaction scale, developed by Chen and his friends (2009) and adapted into Turkish by Turunç and Çelik (2012). The scale consists of 5 statements such as "I feel satisfied with my job", "I feel happy at work", and "When I'm doing my job, I feel as if the day will never end". The 5 Likert Type scale was used.

To be able to determine the construct validity of the scales, exploratory factor analyses were done and the result of the analyses showed with their original. The confirmatory factor analyses, which were done after that, showed that measures of goodness of fit obtained by the factor structures are within the acceptable limits. The summary of the exploratory factor analyses results are shown in Table 2 and the confirmatory factor analyses results are shown in Table 3.

Table 2. Exploratory factor analysis results

\begin{tabular}{lllllll}
\hline Scales & Factors & KMO Result & Barlett Test & Items Number Factor Loads & Proportion of Variance Explained \\
\hline Emotional Labor & EL & 0.869 & 0.000 & 13 & $0.76-0.84$ & 72.12 \\
Leader-Member Exchange & LMX & 0.859 & 0.000 & 7 & $0.56-0.78$ & 69.81 \\
Turnover Intention & TOI & 0.794 & 0.000 & 4 & $0.48-0.85$ & 53.44 \\
Job Satisfaction & JS & 0.779 & 0.000 & 5 & $0.83-0.88$ & 57.85 \\
\hline
\end{tabular}

Table 3. Confirmatory factor analysis results

\begin{tabular}{|c|c|c|c|c|c|c|c|c|c|}
\hline \multirow{2}{*}{ Variables } & \multirow{2}{*}{$X^{2}$} & \multirow{2}{*}{$\mathrm{DF}$} & CMIN/DF & GFI & AGFI & CFI & NFI & NNFI & RMSEA \\
\hline & & & $<5$ & $\geq .90$ & $\geq .85$ & $\geq .95$ & $\geq .90$ & $\geq .90$ & $<.10$ \\
\hline EL & 135.569 & 57 & 2.378 & 0.946 & 0.914 & 0.970 & 0.950 & 0.959 & 0.062 \\
\hline TMX & 42.369 & 10 & 4.237 & 0.967 & 0.908 & 0.969 & 0.960 & 0.967 & 0.095 \\
\hline TOI & 4.989 & 3 & 1.663 & 0.987 & 0.954 & 0.995 & 0.991 & 0.992 & 0.056 \\
\hline JS & 7.403 & 4 & 1.851 & 0.992 & 0.969 & 0.995 & 0.989 & 0.991 & 0.049 \\
\hline
\end{tabular}

Before going on with the study analyses, as holistic paradigm was preferred in the analysis of the variables in this study, weighted mean average was used to calculate the score for emotional labor which consists of more than one factor structure and this value was used in the analyses. For the internal validity of the scales, the calculated Cronbach's alpha coefficients are $\mathrm{EL}=0.88 ; \mathrm{JS}=0.93 ; \mathrm{TOI}=0.76 ; \mathrm{LMX}=0.87$. The results gained by these analyses proved that the scales are valid and reliable for this sample group.

\subsubsection{Control Variables}

In this study, the ages and tenure of the employees in the company are considered as control variables. Many studies have shown that age and tenure affect employees' resignation plans and their turnover intention (Mobley, 1982). Therefore, while analyzing the effects of other variables on employees' turnover intention, their age and tenure are treated as control variables.

\section{Results}

In the first step of the study the averages of the variable data, standard deviation and the correlation among them are considered. The averages, standard deviations and correlation values gathered at the end of the analysis are presented in Table 4. As the consequence of the analysis, it was discovered that there are significant relationships among the variables. Emotional labor has a negative relationship with leader-member exchange $(\mathrm{r}=-0.201, p<$ $0.01)$ and job satisfaction $(\mathrm{r}=-0.119, p<0.05)$ but it has a positive relationship with turnover intention $(\mathrm{r}=0.110$, $p<0.05)$. Leader-member exchange has a negative relationship with turnover intention $(\mathrm{r}=-0.310, p<0.01)$ and has a positive relationship with job satisfaction $(\mathrm{r}=0.484, p<0.01)$. There is a negative relationship between turnover intention and job satisfaction $(\mathrm{r}=-0.447, p<0.01)$. 
Table 4. Average, standard deviation and correlation values of variables

\begin{tabular}{lllllll}
\hline Variables & Mean & SD & 1 & 2 & 3 & 4 \\
\hline EL & 3.47 & 1.06 & 1 & $-0.201^{* *}$ & $0.110^{*}$ & $-0.119^{*}$ \\
LMX & 3.64 & 0.84 & $-0.201^{* *}$ & 1 & $-0.310^{* *}$ & $0.484^{* *}$ \\
TOI & 2.96 & 0.91 & $0.110^{*}$ & $-0.310^{* *}$ & 1 & $-0.447^{* *}$ \\
JS & 3.57 & 0.83 & $-0.119^{*}$ & $0.484^{* *}$ & $-0.447^{* *}$ & 1 \\
\hline
\end{tabular}

${ }^{*} \mathrm{p}<0.05,{ }^{* * \mathrm{p}}<0.01,{ }^{* * *} \mathrm{p}<0.001$.

In the second step of the analysis, whether leader-member exchange has a moderating role on the relationships of emotional labor between turnover intention and job satisfaction was examined. The moderating role is the changing of the relationship between two variables on different levels of a third variable. The moderating variable is defined as a third variable which affects the direction or the power of the relationship between the dependent and the independent variable (Baron \& Kenny, 1986). To analyze the moderating effect, Baron and Kenny's analysis method was used. To analyze the moderating effect, the moderating variable and the independent variable is multiplied and interaction variable is obtained. If the interaction variable is significant, the moderating role's presence will be confirmed (Baron \& Kenny, 1986).

Hierarchical regression analyses were done to determine whether leader-member exchange has a moderating role or not. During the analyses, collinearity was also tested to determine whether there is a multicollinearity problem in the model. The obtained tolerance and VIF values confirmed that there is no multicollinearity among the independent variables (Tolerance $>0.2, \mathrm{VIF}<10$ ).

In the hierarchical regression analysis done to test $\mathrm{H}_{1}$ and $\mathrm{H}_{2}$ hypotheses, age, education and tenure in the current workplace, were used as control variables, emotional labor was used as the independent variable, turnover intention as the dependent variable and leader-member exchange as the moderating variable; the results of this analysis are presented in Table 5. Emotional labor and leader-member exchange variables were centralized before regression analyses (Aiken \& West, 1991, Cohen, West, \& Aiken, 2003) and interaction variable was obtained as a result of the multiplication of the two centralized variables.

Table 5. The hierarchical regression analyses results concerning the moderating role of LMX on how EL affects TOI

\begin{tabular}{llllll}
\hline Step 1 & $\beta$ & Step 2 & $\beta$ & Step 3 & $\beta$ \\
\hline Age & $-0.125^{*}$ & Age & $-0.109^{*}$ & Age & $-0.109^{*}$ \\
Education & -0.068 & Education & -0.029 & Education & -0.028 \\
Tenure & -0.041 & Tenure & -0.013 & Tenure & -0.013 \\
EL & $-0.114^{*}$ & EL & $-0.106^{*}$ & EL & $-0.105^{*}$ \\
& & LMX & $-0.302^{* * *}$ & LMX & $-0.301^{* * *}$ \\
& & & EL x LMX & -0.053 \\
\hline $\mathrm{R}^{2}$ & 0.170 & $\mathrm{R}^{2}$ & 0.343 & $\mathrm{R}^{2}$ & 0.123 \\
$\Delta \mathrm{R}^{2}$ & 0.029 & $\Delta \mathrm{R}^{2}$ & 0.118 & $\Delta \mathrm{R}^{2}$ & 0.113 \\
$\mathrm{~F}$ & $2.638^{*}$ & $\mathrm{~F}$ & $9.428^{* * *}$ & $\mathrm{~F}$ & $12.722^{* * *}$ \\
\hline
\end{tabular}

${ }^{*} \mathrm{p}<0.05, * * \mathrm{p}<0.01, * * * \mathrm{p}<0.001$.

These analyses showed that the relationship between emotional labor and turnover intention is positive and significant $(\beta=-0.105, \mathrm{p}<0.05)$, and therefore, hypothesis $\mathrm{H}_{1}$ has been accepted. According to this, the increase in emotional labor level is a factor which increases the turnover intention of the employees.

In the analysis of the moderating role, the interaction variable (EL x LMX) which was calculated as it was suggested by Baron and Kenny (1986) was included in the regression model and it was proved that it has no significant effect on turnover intention $(\beta=0.053, \mathrm{p}<0.05)$. As a consequence, no moderating role of leader-member exchange on the relationship of emotional labor and turnover intention was found. According to this result, Hypothesis $\mathrm{H}_{2}$ has been rejected.

Collinearity was also tested to determine whether there is a problem of multicollinearity in the model during the 
hierarchical regression analyses. The obtained tolerance and VIF variables confirmed that there was no multicollinearity among the variables (Tolerance $>0.2, \mathrm{VIF}<10$ ).

In the hierarchical regression analysis to test the hypotheses $\mathrm{H}_{3}$ and $\mathrm{H}_{4}$, age, education and tenure in the current workplace were used as control variables, emotional labor was used as the independent variable, job satisfaction as the dependent variable and leader-member exchange as the moderating variable and the results of these analyses are presented in Table 6. Emotional labor and leader-member exchange variables were centralized before regression analyses (Aiken \& West, 1991; Cohen et al., 2003) and interaction variable was obtained as a result of the multiplication of the two centralized variables (EL x LMX).

Table 6. The hierarchical regression analyses results concerning the moderating role of LMX on how EL affects JS

\begin{tabular}{llllll}
\hline Step 1 & $\beta$ & Step 2 & $\beta$ & Step 3 & $\beta$ \\
\hline Age & -0.012 & Age & -0.010 & Age & -0.010 \\
Education & -0.088 & Education & -0.029 & Education & -0.024 \\
Tenure & -0.042 & Tenure & -0.006 & Tenure & -0.001 \\
EL & $-0.156^{* *}$ & EL & $-0.104^{*}$ & EL & $-0.106^{*}$ \\
& & LMX & $-0.470^{* * *}$ & LMX & $-0.472^{* * *}$ \\
& & & EL x LMX & $-0.112^{*}$ \\
$\mathrm{R}^{2}$ & 0.181 & $\mathrm{R}^{2}$ & 0.495 & $\mathrm{R}^{2}$ & 0.508 \\
$\Delta \mathrm{R}^{2}$ & 0.033 & $\Delta \mathrm{R}^{2}$ & 0.245 & $\Delta \mathrm{R}^{2}$ & 0.258 \\
$\mathrm{~F}$ & $2.996^{*}$ & $\mathrm{~F}$ & $23.008^{* * *}$ & $\mathrm{~F}$ & $20.432^{* * *}$ \\
\hline
\end{tabular}

${ }^{*} \mathrm{p}<0.05, * * \mathrm{p}<0.01, * * * \mathrm{p}<0.001$.

These analyses showed that the relationship between emotional labor and job satisfaction is negative and significant $(\beta=-0.156, \mathrm{p}<0.01)$ and hypothesis $\mathrm{H}_{3}$ has been accepted. According to this, the increase in emotional labor level affects employees' job satisfaction negatively.

In the analysis of the moderating role, the interaction variable (EL x LMX) which was calculated as it was suggested by Baron and Kenny (1986) was included in the regression model and it was proved that it has a significant and negative effect on job satisfaction $(\beta=-0.112, \mathrm{p}<0.05)$. As a consequence, it was found out that leader-member exchange has a moderating role on the relationship between emotional labor and job satisfaction. According to this result, Hypothesis $\mathrm{H}_{4}$ has been accepted.

Apart from this, to have a more detailed analysis on the direction of the relationship, the significance of the relationships between emotional labor and turnover intention, when leader-member exchange is low and when it is high, were tested by a regression curve (Figure 2) (Aiken \& West, 1991; Cohen et al., 2003).

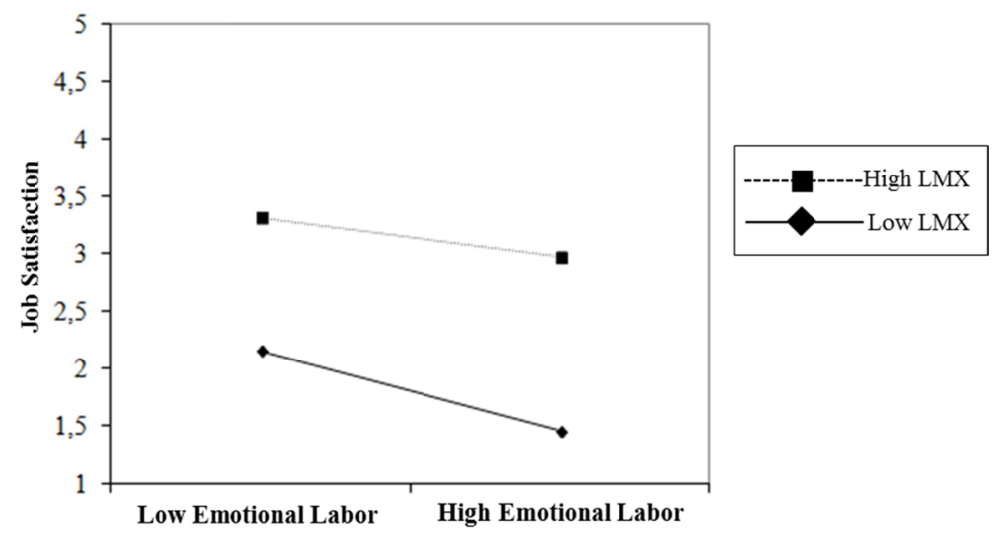

Figure 2. The moderating role of LMX on the relationship between EL and JS 
How the relationship between emotional labor and job satisfaction changes for the different levels (high and low) of leader-member exchange in Figure 2 is analyzed by the help of Aiken and West's (1991) simple slopes analysis. In low and high levels of leader-member exchange values different than zero were obtained. Although the relationship between emotional labor and job satisfaction continues in a negative way in certain levels of leader-member exchange, it is possible to state that when leader-member exchange is high, this relationship weakens. As a result of the interaction of emotional labor and leader-member exchange variables, the whole model explains the $24.5 \%$ of the variance. This finding confirms the one concerning the acceptance of hypothesis $\mathrm{H}_{4}$ obtained by the help of the regression analysis and it shows that leader-member exchange has a moderating role on the relationship between emotional labor and turnover intention.

\section{Discussion \& Conclusion}

With the constrictions in market conditions and the cost restrictions in the world economy which have reached to their final point, business organizations, seeking for a way out have been becoming more and more desperate in finding a solution. Especially when it is considered that the only and the most important production factor is the human, the problem grows even bigger. Under these circumstances, the organizations looking for solutions, are expecting the employees who have face to face communication with the customers to serve them in every way in the pre or post sale period to gain some new skills. This study was fictionalized as it was thought leader-member exchange quality might have a significant moderating role on the relationships between emotional labor, which is considered as one of these new skills, andJS, a positive business manner, which affects the performances of the employees directly or turnover intention, a negative business manner. The analysis of the moderating role of leader-member exchange in the relationships between EL-TOI and EL-JS adds distinction to this study.

The analyses applied on the data obtained has shown that there is a positive and significant relationship between emotional labor and turnover intention $\left(\mathrm{H}_{1}=+\right)$. Therefore, an increase in the emotional labor level is a variable which increases turnover intention. However, a negative and significant relationship $\left(\mathrm{H}_{3}=+\right)$ between emotional labor and job satisfaction has been found. This means that the increase in emotional labor level affects job satisfaction negatively. At the end of these analyses, the results obtained in EL-TOI or EL-JS relationships, are similar to the ones obtained before. During this process it has been proved that despite the fact that the employees who perform high emotional labor during their relations with customers contribute to their organizations, the emotional dilemmas they experience in their inner world, decrease their job satisfaction and increase turnover intention.

In the analyses done to measure the moderating role of leader-member exchange quality, it has been found out that leader-member exchange has no moderating role on EL-TOI relationship $\left(\mathrm{H}_{2}=-\right)$. It has been proved that leader-member exchange quality has no moderating role on turnover intention although high interaction level of the members with their leaders was expected to play a moderating role as turnover intention, one of the natural results of emotional negations employees experience when they display high emotional labor, is expected to increase.

The reason for obtaining such a result contradicting with what was expected at the beginning, the deterioration of leader-member exchange's moderating role by the effect of turnover intention's eight motivators (i.e., affective, calculative, contractual, behavioral, alternative, normative, moral/ethical, and constituent) determined by Maertz and Griffeth, (2004), could be mentioned. Affective, calculative and alternative motivators especially, are believed to deteriorate the moderating role of leader-member exchange quality. For this reason, as for turnover intention, which is considered an important decision for employees and 'the beginning of the end', employees continue their efforts by the effects of these motivators with determination. And in the sector where this study was done, factors such as labor turnover being high in some lower positions and job opportunities not being limited were considered effective.

In this respect, as members who have low-quality and middle-quality leader-member exchange relations with their leaders are realized to be forced to go out of the system, members who have high-quality leader-member exchange relations with their leaders are trying to go out of the system by the effects of the motivators contrary to the expected. To create high-quality leader-member exchange relations enable the members to obtain more sources, to get more opportunities of new trips, courses, seminars; to be trusted and regarded by the management and to feel themselves more valued. Because of these reasons, employees with high self-confidence who have the faith to succeed in alternative positions, business and organizational environments are even claimed to be supported by their leaders on this issue to gain more material and moral benefits and new opportunities.

In the studies which analyze the relationships of LMX-TOI and LMX-JS in literature, when low-quality and middle-quality leader-member exchange is enabled, it was determined that when job satisfaction decreases, 
turnover intention increases, and in high-quality leader-member exchange relations, when job satisfaction increases, turnover intention doesn't decrease; on the contrary it increases. In LMX-TOI relations, the reason for high-quality leader-member exchange causing an increase in turnover intention instead of a decrease is claimed to be eight motivators.

Besides that, the presence of the moderating role of leader-member exchange in the negative relationship between emotional labor and job satisfaction $\left(\mathrm{H}_{4}=+\right)$ is approved. According to this, when employees perform high emotional labor, job satisfaction might decrease, however, the moderating role of high quality interaction members will have with their leaders will contribute to the increase of job satisfaction again. It has been proved that emotional labor has a significant effect especially on job satisfaction, concerning the organization or decrease of the emotional dilemmas of the employees who are able to create high quality leader-member exchange with their leaders in the workplace, especially in the working areas where emotional labor is used intensively. As a consequence, job dissatisfaction, a negative business manner which is not at its final point yet, although it depends on the quality of leader-member exchange may have a moderating role at the beginning for analysis.

So as a result, it has been stated that although employees' directing their emotions towards organizational goals and expectations has positive effects on organizational success, it may have negative outcomes as for the individuals. Having to feel the emotions which are not written in their job descriptions cause employees to experience emotional dilemmas. They are expected to perform emotional labor in order to continue serving the customers in a friendly way because of the motto "the customer is always right" resulting from the concept of "being customer-focused" and with this concept of modern service manner they have to deal with some problematic situations in cargo companies such as rude customers, wrong addresses, not being able to find at the given address, wrong receipts, delays and returns.

In addition to these negativities employees experience, their perception of "what they gain does not meet their requirements" leads them to experience less job satisfaction and even job dissatisfaction. Therefore, employees who experience job dissatisfaction will inevitably experience turnover intention in the near future. Therefore, managers and human resources departments of the organizations should take into consideration that emotional incompatibility resulting from emotional labor, which may cause an increase in organizational success in the short run, may have negative outcomes on the employees in the long run and this situation might affect organizational success negatively again in the long run.

In this respect, leaders' paving the way for a better interaction will make the members feel themselves more valued. Businesses organizing trainings concerning this issue will help them face fewer problems about emotional labor.

In literature although there are studies analyzing the relationships between emotional labor, turnover intention and job satisfaction, there are very few studies on these in national literature. Besides, no studies were found analyzing the moderating role of leader-member exchange on the relationship between these variables. The study is expected to contribute to literature especially in this respect.

There are some limitations in this study. The most important limitation is the study was done on the employees working in the branches of cargo in a logistic firm. So it is considered as inadequate as it represents neither the whole sector nor the whole nation. To generalize the results of the study, it should be done on larger sample groups, in different geographical regions and in different sectors.

Apart from this, especially in sectors where job opportunities don't allow job changes relatively, the repetition of this study might help to determine whether the variable leader-member exchange has a moderating role on the relationship of EL-TOI.

Displaying emotional labor has also two sides within the framework of vertical dyadic relations to which the theory of leader-member exchange refers to. So trusted and respected leaders who encourage their members to choose the right emotions and display emotional labor, are also expected to display emotional labor themselves. But due to the limitations of this study, only the emotional labor perceptions of the employees have been studied. In addition, although in the factor analysis of the scale used in analyzing the emotional labor perceptions of the employees, three sub factors were determined, with a holistic approach, determining it as a single factor assuming it significant and valid with its causes might be considered as a limitation. On the other hand, while the moderating role of leader-member exchange was being analyzed, employees' perceptions about the motivators that motivate their turnover intention not being measured could be considered another important limitation. Using a scale which includes motivators that motivate turnover intention for future studies would be favorable. 


\section{References}

Abraham, R. (1999). Emotional dissonance in organizations: What is its impact on organizational commitment and intention to turnover. Journal of Psychology, 133(4), 441-455. http://dx.doi.org/10.1080/00223989909599754

Adams, J. S. (1963). Toward an understanding of inequity. Journal of Abnormal and, Social Psychology, 67(5), 422-436. http://dx.doi.org/10.1037/h0040968

Aiken, L. S., \& West, S. G. (1991). Multiple regression: Testing and interpreting interactions. Newbury Park, Sage Publications, CA.

Akgeyik, T., \& Güngör, M. (2013). Müşteriden kaynaklanan (psikolojik taciz) saldırgan davranışlar: Market ve çağrı merkezi çalışanlarına ilişkin bir araştırma, 1. Basım, Özyurt Matbaacılık, Ankara.

Ashforth, B. E., \& Humphrey, R. H. (1993). Emotional labor in service roles: the influence of identity. The Academy of Management Review, 18(1), 88-115.

Ashkanasy, N. M., \& Humphrey, R. H. (2011). A multi-level view of leadership and emotions: Leading with emotional labor. In A. Bryman, D. Collinson, K. Grint, B. Jackson, \& M. Uhl-Bien (Eds.), Sage handbook of leadership (pp. 363-377). London: Sage Publications.

Aylan, S., (2012). Organizasyonlarda psikolojik şiddet (mobbing) ve işten ayrlma niyeti arasındaki ilişkiyi tespit etmeye yönelik konaklama işletmelerinde bir uygulama. Yayınlanmamış Yüksek Lisans Tezi, Gazi Üniversitesi Eğitim Bilimleri Enstitüsü, Ankara.

Bang, H. (2011). Leader-member exchange in nonprofit sport organizations the impact on job satisfaction and intention to stay from the perspectives of volunteer leaders and followers. Nonprofit Management \& Leadership, 22(1), 85-105. http://dx.doi.org/10.1002/nml.2004

Baron, R. M., \& Kenny, D. A. (1986). The moderator mediator variable distinction in social psychological research: Conceptual, strategic, and statistical considerations. Journal of Personality and Social Psychology, 51, 1173-1182. http://dx.doi.org/10.1037/0022-3514.51.6.1173

Başbuğ, G., Ballı, E., \& Oktuğ, Z. (2010). Duygusal emeğin iş memnuniyetine etkisi: Çağrı merkezi çalışanlarına yönelik bir araştırma. Istanbul Üniversitesi Sosyal Siyaset Konferansları Dergisi, 58(1), 253-274.

Basım, N., \& Beğenirbaş, M. (2012). Çalışma yaşamında duygusal emek: Bir ölçek uyarlama çalışması. Yönetim ve Ekonomi, 19(1), 77-90.

Bauer, T. N., \& Green, S. G. (1996). Development of leader member exchange: A longitudinal test. Academy of Management Journal, 39(6), 1538-1567. http://dx.doi.org/10.2307/257068

Beğenirbaş, M., \& Çalışkan, M. (2014). Duygusal emeğin iş performansı ve işten ayrılma niyetine etkisinde kişilerarası çarpıklığın aracılık rolü. Business and Economics Research Journal, 5(2), 109-127.

Biçkes, D. M., Yılmaz, C., Demirtaş, Ö., \& Uğur, A. (2014). Duygusal emek ile iş tatmini arasındaki ilişkide psikolojik sermayenin aracılık rolü: Bir alan çalışması. Eskişehir Orhangazi Üniveristesi, İBF Dergisi, 9(2), 97-121.

Blau, P. M. (1964). Exchange and Power in Social Life. New York: Wiley.

Bouckenooghe, D., Raja, U., \& Butt, A. N. (2013). Combined effects of positive and negative affectivity and job satisfaction on job performance and turnover intentions. The Journal of Psychology: Interdisciplinary and Applied, 147(2), 105-123. http://dx.doi.org/10.1080/00223980.2012.678411

Brotheridge, C. M., \& Grandey, A. (2002). Emotional labor and burnout: Comparing two perspectives of people work. Journal of Vocational Behavior, 60(1), 17-39. http://dx.doi.org/10.1006/jvbe.2001.1815

Buch, R. (2015). Leader-member exchange as a moderator of the relationship between employee-organization exchange and affective commitment. The International Journal of Human Resource Management, 26, 59-79. http://dx.doi.org/10.1080/09585192.2014.934897

Burns, J. Z., \& Otte, F. L. (1999). Implications of leader-member exchange theory and research for human resource development research. Human Resource Development Quarterly, 10(3), 225-248. http://dx.doi.org/10.1002/hrdq.3920100304

Çekmecelioğlu, H. G., \& Ülker, F. (2014). Lider üye etkileşimi ve çalışan tutumları üzerindeki etkisi: Eğitim sektöründe bir araştırma. KOSBED Dergisi, 28, 35-58. 
Chau, S. L., Dahling J. J., Levy, P. E., \& Diefendorff, J. M. (2009). A predictive study of emotional labor and turnover. Journal of Organizational Behavior, 30(8), 1151-1163. http://dx.doi.org/10.1002/job.617

Chen, F. C., Ku, E. C. S., Shyr Y. H., Chen, F. H., \& Chou, S. S. (2009). Job demand, emotional awareness, and job satisfaction in internships: The moderating effect of social support. Social Behavior and Personality, 37(10), 1429-1440. http://dx.doi.org/10.2224/sbp.2009.37.10.1429

Cohen, J., Cohen, P., West, S. G., \& Aiken, L. S. (2003). Applied multiple regression/correlation analysis for the behavioral sciences. Mahwah, Lawrence Erlbaum Associates, New Jersey.

Cote, S., \& Morgan, L. M. (2002). A Longitudinal analysis of the association between emotion regulation, job satisfaction, and intentions to quit. Journal of Organizational Behavior, 23, 947-962. http://dx.doi.org/10.1002/job.174

Dansereau, F., Graen, G. B., \& Haga, W. (1975). A vertical dyad linkage approach to leadership in formal organizations. Organizatonal Behavior and Human Performance, 13, 46-78. http://dx.doi.org/10.1016/0030-5073(75)90005-7

Diefendorff, J. M., Croyle, M. H., \& Grosserand, R. H. (2005). The dimensionality and antecedents of emotinal labor strategies, Journal of Vocational Behavior, 66, 339-357. http://dx.doi.org/10.1016/j.jvb.2004.02.001

Diefendorff, J. M., Morehart, J., \& Gabriel, A. (2010). The influence of power and solidarity on emotional display rules at work. Motiv Emot, 34(2), 120-132. http://dx.doi.org/10.1007/s11031-010-9167-8

Epidropaki, O., \& Martin, R. (2005). From ideal to real: A longitudinal study of the role of implicit leadership theories on the LMX and employee outcomes. Jounal of Applied Psychology, 90(4), 659-676. http://dx.doi.org/10.1037/0021-9010.90.4.659

Gardner, W. L., Fischer, D., \& Hunt, J. G. (2009). Emotional labor and leadership: A threat to authenticity? Leadership Quarterly, 20, 466-482. http://dx.doi.org/10.1016/j.leaqua.2009.03.011

Gerstner, C. R., \& Day, D. V. (1997). Meta-analytic review of leader-member exchange theory: Correlates and construct issues. Journal of Applied Psychology, 82(6), 827-844. $\mathrm{http}: / / \mathrm{dx}$.doi.org/10.1037/0021-9010.82.6.827

Ghalandari, K., \& Jogh, M. G. G. (2012). The effect of emotional labor strategies (surface acting and deep acting) on job satisfaction and job burnout in Iranian organizations: The role of emotional intelligence. Interdisciplinary Journal of Research in Business, 1(12), 24-31.

Glomb, T. M., \& Tews, M. J. (2004). Emotional labor: A conceptualization and scale development. Journal of Vocational Behavior, 64, 1-23. http://dx.doi.org/10.1016/S0001-8791(03)00038-1

Goodwin, R. E., Groth, M., Frenkel, S. J. (2011). Relationships between emotional labor, job performance, and turnover. Journal of Vocational Behavior, 79, 538-548. http://dx.doi.org/10.1016/j.jvb.2011.03.001

Gosserand, R. H., \& Dienfendorff, J. M. (2005). Display rules and emotional labor: The moderating role of commitment. J. Applied Psychology, 90(6), 1256-1264. http://dx.doi.org/10.1037/0021-9010.90.6.1256

Graen, G. B., \& Scandura, T. A. (1987). Toward a psychology of dyadic organizing. Research in Organizational Behavior, 9, 175-208. http://dx.doi.org/10.1016/1048-9843(95)90036-5

Graen, G. B., \& Uhl-Bien, M. (1995). Relationship-based approach to leadership: Development of leader-member exchange (LMX) theory of leadership over 25 years: Applying a multi-level multi-domain perspective. Leadership Quarterly, 6(2), 219-247.

Grandey, A. A. (2003). When the show must go on: Surface acting and deep acting as determinants of emotional exhaustion and peer-rated service delivery. Academy of Management Journal, 46, 86-96. http://dx.doi.org/10.2307/30040678

Grandey, A. A., Fisk, G. M., Mattila, A. S., Jansen, K. J., \& Sideman, L. A. (2005). Is 'service with a smile' enough? Authenticity of positive displays during service encounters. Organizational Behavior and Human Decision Processes, 96, 38-55. http://dx.doi.org/10.1016/j.obhdp.2004.08.002

Gül, H., E. Oktay, \& Gökçe, H. (2008). İş tatmini, stres, örgütsel bağlllık, işten ayrılma niyeti ve performans arasındaki ilişkiler: Sağlık sektöründe bir uygulama. Akademik Bakış, Sayı, 15, 1-11.

Güngör, M. (2009). Duygusal emek kavramı: Süreci ve sonuçları. Kamu-İs, 11(1), 167-184.

Güzel, F. Ö., Gök A. G., \& Büyüker İ. D. (2013). Duygusal emek ve işten ayrılma niyeti ilişkisi: Turist rehberleri üzerinde bir araştırma. Seyahat ve Otel İşletmeciliği Dergisi, 10(3), 107-123. 
Harris, K. J., Kacmar, K. M., \& Witt, L. A. (2005). An examination of the curvilinear relationship between leader- member exchange and intent to turnover. Journal of Organizational Behavior, 26, 363-378. http://dx.doi.org/10.1002/job.314

Herzberg, F., Mausner, B., \& Snyderman, B. B. (2011). The Motivation to Work with a new introduction by Fererick Herzberg. New York, USA: Transaction Publishers.

Hochschild, A. R. (1983). The managed hearth: Commercialization of human feeling. Berkeley, University of California.

Hom, P. W., Caranikas, W. F., Prussia, G. E., \& Griffeth, R. W. (1992). A meta-analytical structural equations analysis of a model of employee turnover. Journal of Applied Psychology, 77, 890-909. http://dx.doi.org/10.1037/0021-9010.77.6.890

Humphrey, R. H. (2012). How do leaders use emotional labor? Journal of Organizational Behavior, 33, 740-744. http://dx.doi.org/10.1002/job.1791

Janssen, O., \& Yperen, N. W. V. (2004). Employees' goal orientations, the quality of leader-member exchange, and the outcomes of job performance and job satisfaction. Academy of Management Journal, 47(3), 368-384. http://dx.doi.org/10.2307/20159587

Jiang, X., Jiang, Z., \& Park, Y. (2013). Emotional labor strategy and job satisfaction: A Chinese perspective. Social Behavior and Personality, 41(6), 933-938. http://dx.doi.org/10.2224/sbp.2013.41.6.933

Judge, T. A., Woolf, E. F., \& Hurst, C. (2009). Is emotional labor more difficult for some than for others? A multilevel, experience-sampling study. Personnel Psychology, 62, 57-88. http://dx.doi.org/10.1111/j.1744-6570.2008.01129.x

Jyoti, J. (2013). Impact of organizational climate on job satisfaction, job commitment and intention to leave: An empirical model. Journal of Business Theory and Practice, 1(1), 66-82.

Kahn, R. L., Wolfe, D. M., Quinn, R. P., Snoek, J. D., \& Rosenthal, R. A. (1964). Organizational Stress: Studies in Role Conflict and Ambiguity. New York: Wiley.

Karcıoğlu, F., \& Kahya, C. (2011). Lider-üye etkileşimi ve çatışma yönetim stili ilişkisi. Atatürk Üniversitesi Sosyal Bilimler Dergisi, 15(2), 337-352.

Kart, E. (2011). Bir duygu yönetimi süreci olarak duygusal emeğin çalışanlar üzerindeki etkisi. Çallş̧a ve Toplum, 3(30), 215-230.

Locke, E. A. (1976). The nature and causes of job satisfaction. In M. D. Dunnett (Ed.), Handbook of industrial and organizational psychology (pp. 1279-1350). Rand McNally, Chicago.

Lunenburg, F. C. (2010). Leader-member exchange theory: Another Perspective on the leadership process. International Journal of Management, Business, and Administration, 13(1), 1-5.

Maertz, C. P., \& Griffeth, R. W. (2004). Eight motivational forces and voluntary turnover: A theoretical synthesis with implications for research. Journal of Management, 30, 667-83. http://dx.doi.org/10.1016/j.jm.2004.04.001

Maslyn, J. M., \& Uhl-Bien, M. (2001). Leader-member exchange and its dimensions: Effects of self-effort and other's effort on relationship quality. Journal of Applied Psychology, 86(4), 697-708. http://dx.doi.org/10.1037/0021-9010.86.4.697

Mobley, W. H. (1982). Some unanswered questions in turnover and withdrawal research. The Academy of Management Review, 7(1), 111-116.

Morris, J. A., \& Feldman, D. C. (1997). Managing emotions in the workplace. Journal of Managerial Issues, 9(3), 257-274.

Morrow, P. C., Suzuki, Y., Crum, M. R., Ruben, R., \& Pautsch, G. (2005). The role of leader-member exchange in high turnover work environments. Journal of Managerial Psychology, 20(8), 681-694. http://dx.doi.org/10.1108/02683940510631444

Nishii, L. H., \& Mayer, D. M. (2009). Do inclusive leaders help to reduce turnover in diverse groups? The moderating role of leader-member exchange in the diversity to turnover relationship. Journal of Applied Psychology, 94(6), 1412-1426. http://dx.doi.org/10.1037/a0017190

Oral, L., \& Köse, S. (2011). Hekimlerin duygusal emek kullanımı ile iş doyumu ve tükenmişlik düzeyleri arasındaki ilişkiler üzerine bir araştırma. Süleyman Demirel University Journal of Faculty of Economics \& 
Administrative Sciences, 16(2), 463-492.

Öz, E. Ü. (2007). Duygusal emek davranışlarının çalı̧̧anların işs sonuçlarına etkisi. Beta Basım Yayım Dağıtım A. Ş., İstanbul.

Özdemir, G., Yalçın, M., \& Akbıyık M. (2013). Hizmet sektöründe duygusal emek davranışlarının müşteri ilişkileri üzerindeki etkisi: Boyner örneği. NWSA-Humanities, 8(3), 301-320. http://dx.doi.org/10.12739/NWSA.2013.8.3.4C0170

Özutku, H., Ağca, V., \& Cevrioğlu, E. (2008). Lider-üye etkileşim teorisi çerçevesinde, yönetici-ast etkileşimi ile örgütsel bağlılık boyutları ve iş başarımı arasındaki ilişki: Ampirik bir inceleme. İktisadi ve İdari Bilimler Dergisi, 22(2), 193-210.

Şahin, F. (2011). Lider-üye etkileşimi ile işten ayrılma niyeti arasındaki ilişki üzerinde cinsiyetin etkisi. Ege Akademik Bakış Dergisi, 11(2), 277-278.

Scandura, T. A., \& Graen, G. (1984). Moderating effects of initial leader-member exchange status on the effects of a leadership intervention. Journal of Applied Psychology, 69(3), 428-436. http://dx.doi.org/10.1037/0021-9010.69.3.428

Scott, C. R., Connaughton, S. L., Diaz-Saenz, H. R., Maguire, K., Ramirez, R., Richardson, B., Shaw, S. P., \& Morgan, D. (1999). The impacts of communication and multiple identifications on intent to leave: A multimethodological exploration. Management Communication Quarterly, 12(3), 400-435. http://dx.doi.org/10.1177/0893318999123002

Smuts, H. J. C. (1927). Holism and Evolution. USA: Macmillan and Company Limited.

Tokmak, İ. (2014). Duygusal emek ile işe yabancılaşma ilişkisinde psikolojik sermayenin düzenleyici etkisi. Işsletme Araştırmaları Dergisi, 6(3), 134-136.

Turunç, Ö., \& Çelik, M. (2012). İş tamini-kişi-örgüt uyumu ve amire güven-kişi örgüt uyumu ilişkisinde dağıtım adaletinin düzenleyici rolü İş. Gü̧ Endüstri İlişkileri ve İnsan Kaynakları Dergisi, 14(2), 57-78.

Ural, A., \& Kılıç, İ. (2011). Bilimsel araştırma süreci ve SPSS ile veri analizi. Detay Yayıncılık, 3. Basım, Ankara.

Vecchio, R. P., \& Gobdel, B. C. (1984). The vertical dyad linkage model of leadership: Problems and prospects. $\begin{array}{llll}\text { Organizational Behavior and Human Performance, } & \text { 34, }\end{array}$ http://dx.doi.org/10.1016/0030-5073(84)90035-7

Wharton, A. S. (2009). The sociology of emotional labor. Annual Review of Sociology, 35, 147-165. http://dx.doi.org/10.1146/annurev-soc-070308-115944

Yıldırım, M. H., \& Erul, E. E. (2013). Duygusal emek davranışının işgörelerin tükenmişlik düzeylerine etkisi. Organizasyon ve Yönetim Bilimleri Dergisi, 5(1), 88-99.

Yin, H. (2012). Adaptation and validation of the teacher emotional labour strategy scale in China. Educational Psychology: An International Journal of Experimental Educational Psychology, 32(4), 451-465. http://dx.doi.org/10.1080/01443410.2012.674488

\section{Copyrights}

Copyright for this article is retained by the author(s), with first publication rights granted to the journal.

This is an open-access article distributed under the terms and conditions of the Creative Commons Attribution license (http://creativecommons.org/licenses/by/4.0/). 